\title{
INDOOR CONCENTRATION AND COMPOSITION OF FINE PARTICULATE MATTER (PM2.5) NEAR AN INTENSE CIRCULATED ROAD IN AN INDUSTRIAL CITY
}

\author{
Marius BODOR \\ "Dunarea de Jos" University of Galati, Romania \\ e-mail: marius.bodor@ugal.ro
}

\begin{abstract}
The purpose of the present work is to present results from a measuring campaign during February-March 2020, in Galati city, Romania, aiming the concentration of fine particulate matter $\left(P M_{2.5}\right)$ in air and their heavy metal concentrations, then comparing the results with the air quality determined by the national monitoring system from the same city. Results show considerable differences concerning the air quality measured in this study compared with measurements of the national monitoring system that consist in four stations placed across the city. While values recorded in this study exceeded, in some situations, the maximum target from $P M_{2.5}$, the reports from the national monitoring system presented a good air quality, using a colour-and number-coding (maximum level 4 out of 6 was reported). Heavy metal concentrations of the fine particulate matters collected in this study was compared with other studies across the world, high Fe and $\mathrm{Zn}$ values being registered in agglomerated and industrialized cities, including the city considered in the present study, while in a study conducted in Beijing, China most higher values between all analysed heavy metals were recorded.
\end{abstract}

KEYWORDS: air quality, fine particulate maters, X-ray fluorescence

\section{Introduction}

The overall environmental situation in the world made air, water and soil quality monitoring to become compulsory in some situations. Air quality monitoring became compulsory in Romania, according to European Directives, for all urban agglomerations surpassing 100,000 inhabitants [1]. The pollutants taken into consideration and the way the air quality status is presented to the population was also standardized and included into Romanian legislation [2].

During air quality monitoring, two types of particulate matter (PM) dimensions are usually taken into consideration: $\mathrm{PM}_{2.5}$ and $\mathrm{PM}_{10}$, the later one being more frequently tracked, at least according to the Romanian legislation [2, 3]. This might be since this type of particle matter analysis also include the other, finer and more dangerous, PM dimensions: $\mathrm{PM}_{2.5}$. The $\mathrm{PM}_{2.5}$ quantitative analyses represent the determination of cumulative particulate matters mass for particle fraction with a $50 \%$ aerodynamic cutoff diameter of $2.5 \mu \mathrm{m}$ in a known volume of analyzed atmospheric air [4-6]. The effect of this type of pollutant is well documented [7-8] and works are still emerging in the specialized literature, especially in Asia [9-12], where multiple great human agglomerations creates the premises [13] for extremely high values of particulate matters in the atmosphere (e.g.: a mean concentration of 102.45 $\mu \mathrm{g} / \mathrm{m}^{3}$ in Beijing, China, during 2015-2016 period, for $\mathrm{PM}_{2.5}$ ) [14].

This type of pollutant was chosen for the present study since the finer share of particulate matters is considered most dangerous for the human health and although permanent monitoring stations already exist, articles from Eastern Europe are scarce and qualitative analysis of these particulates are even more so. While, as mentioned above, there are some hints regarding the effect of $\mathrm{PM}_{2.5}$ on human health, the corroboration of qualitative analyses and health effect was not identified in the specialized literature and the possibility to do just that might emerge once a sufficient amount of data will be at hand. In this regard, this paper aims to present a comparation of air quality resulted from the local monitoring system and that registered in a residential apartment focused on the quantitative analysis of $\mathrm{PM}_{2.5}$. Also, qualitative 
analysis (heavy metals concentration) was addressed, obtained data being compared with other studies around the world, most of them also focused on indoor $\mathrm{PM}_{2.5}$ determination.

\section{Materials and methods}

The sampling campaign took place in Galati (an approx. 250,000 inhabitants city in south-east of Romania), in a building facing a four-line road with a fairly high traffic (Latitude: 45.433650, Longitude: 28.028543), during February and March 2020. The sampler was placed intermittently ( 24 hours for each filter) in a living room and inside its enclosed balcony (at all times with both balcony and living room windows being tilt-opened) of a residential apartment at the third floor. Against the pollution and noise from the road, as a green buffer (although during the sampling period the trees were without leaves), the building in discussion has a line of trees high enough to reach the fourth floor, situated between the road and the sidewalk near the building. The sampler was placed each time on the floor with its filter holder being situated at a height of $1.2 \mathrm{~m}$.

\subsection{Gravimetric analysis}

In the present study, the same instruments and methodology as in [15] was used. Thus, for $\mathrm{PM}_{2.5}$ collection an Automated Aerosol Sampling Device, type ISAP 1050e, was utilized (Figure 1-left). The flow rate of this device was equal to $2.3 \mathrm{~m}^{3} / \mathrm{h}$. Particulate matters were collected on a glass microfiber with $45 \mathrm{~mm}$ in diameter, a $0.30 \mathrm{~mm}$ in thickness and $0.7 \mu \mathrm{m}$ in pores size (Figure 1-right), the support holder used this time being a specially $\mathrm{PM}_{2.5}$ type one (Figure 1-middle). The filter was placed in the holder, between a rubber garniture and a metallic made mesh as a support. Before and after the aerosols collection, the filter was weighted using an analytical balance (type ALT 220-4NM, from KERN). The particulate matters collection time for each measurement was 24 hours, each time a new filter being used. The quantity of $\mathrm{PM}_{2.5}$, expressed in $\mu \mathrm{g} / \mathrm{m}^{3}$, for one analysis was calculated based on the overall particles mass (gravimetrically analyzed), the volume of air filtered by the sampling device and the functioning time of this device (both values automatically calculated by the sampler and presented in a report and downloaded from the sampling device after each 24 hour functioning time).

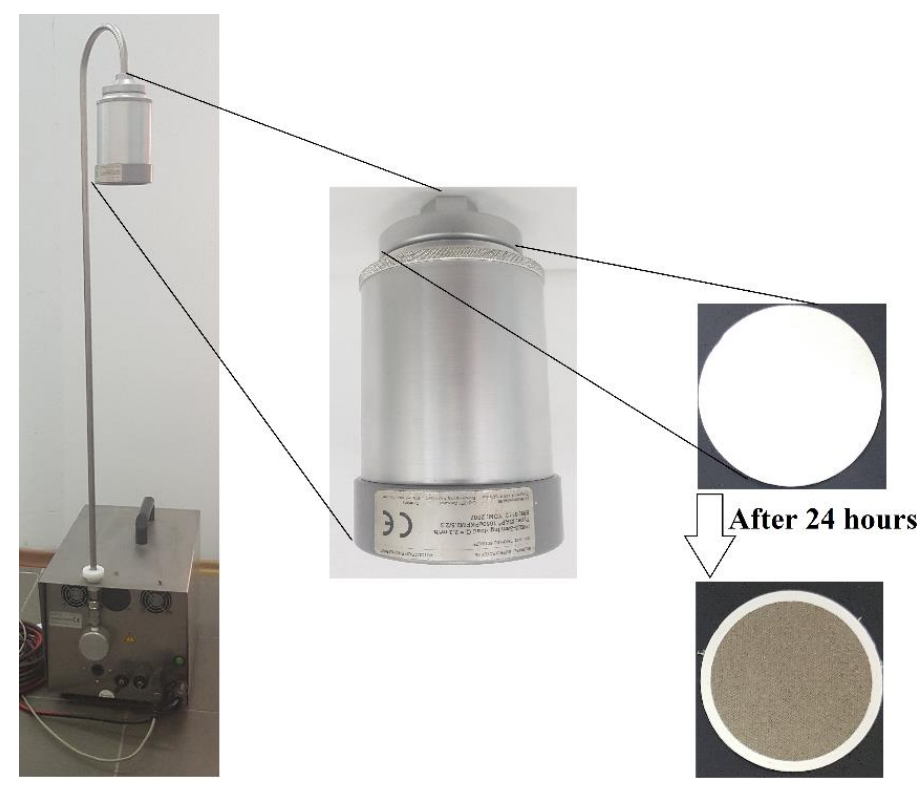

Fig. 1. The Automated Aerosol Sampling Device, type ISAP 1050e, used for PM 2.5 collection (left) and the support holder (middle) for the glass microfiber filter (right-up), blackened by particulate matters after 24-hours utilization (right-down)

\subsection{Qualitative analysis of fine particulate matters}

Before and after a 24-hour functioning of the sampling device, the filter was placed/extracted into/from the holder and weighted. Also, before and after the 24-hour functioning of the sampler, the side chosen to accumulate particulate matters was analyzed to determine the elemental composition using an INNOV-X type ( $\alpha$ A-4000 series) X-ray fluorescence $(\mathrm{XRF})$ spectrometer with an X-ray tube 
with acceleration tension of $40 \mathrm{kV}$, a Si-PiN<280 eV diode detector (thermoelectrically cooled), with 5.95 $\mathrm{eV} / \mathrm{K}-\alpha$ line. The values of XRF analyses represents an average of six separate readings, each reading being done on different surface of the same filter side. This way, most of the filter surface exposed to the intake air was analyzed before and after the sampling, increasing the obtained data solidity. As in [15], the concentration of heavy metals in retained $\mathrm{PM}_{2.5}$ samples was calculated as described in [16]. Thus, the average value mentioned above (expressed in $\mu \mathrm{g} / \mathrm{cm}^{2}$ ) was multiplied with the exposed filter area $(12.56$ $\mathrm{cm}^{2}$, smaller than the actual filter area of $15.89 \mathrm{~cm}^{2}$ ), subtracting the value obtained the same way for the blank filter, then dividing by the air sample volume $\left(55.2 \mathrm{~m}^{3}\right)$ and then multiplying with 1000 so the final data to be expressed in $\mathrm{ng} / \mathrm{m}^{3}$ (Equation 1).

$$
H M C=\left(\frac{\left(A v_{U F}-A v_{B F}\right) \times E F A}{S V}\right) \times 1000,\left[\mathrm{ng} / \mathrm{m}^{3}\right]
$$

where:

HMC - concentration of a certain heavy metal, $\left[\mathrm{ng} / \mathrm{m}^{3}\right]$;

$A v_{U F}$ - average value concentration of a certain heavy metal for a used filter, $\left[\mu \mathrm{g} / \mathrm{cm}^{2}\right]$;

$A v_{B F}$ - average value concentration of a certain heavy metal for a blank filter, $\left[\mu \mathrm{g} / \mathrm{cm}^{2}\right]$;

$E F A$ - exposed filter area $\left(12.56 \mathrm{~cm}^{2}\right)$;

$S V$ - air sample volume $\left(55.2 \mathrm{~m}^{3}\right)$.

The values obtained after performing this analysis were then compared with those from the available literature, also aiming $\mathrm{PM}_{2.5}$ qualitative measurements. The elements detected in this study (Ti, Ba, Cr, Mn, Fe, Zn, Rb and Sr) might not be mentioned in the legislation regarding their maximum permitted values, instead a comparison with other studies might offer an insight related to the fine particulate matters concentration from the elemental point of view.

\section{Results and discussions}

Results of this work, regarding the $\mathrm{PM}_{2.5}$ concentration, were placed in contrast with results from the national monitoring system. The national monitoring system has 4 stations placed inside Galati city and the results are presented on the official website for each measured pollutant [17]. Also, to ease public information, an electric panel placed in a visible place inside the city presents in a color- and number-coded way the situation of air quality. Monthly reports are also available on the official website [18] and those issued for February and March periods were used for comparison in this study.

Since most of heavy metals concentrations in air are not regulated, a comparison was possible only with the available literature and various studies from numerous countries from different continents were selected.

\subsection{Evolution of $P M_{2.5}$ concentration in the analyzed air samples}

Results regarding the $\mathrm{PM}_{2.5}$ concentration are presented in Figure 2, separately presented for living room and balcony sampling. Also, according to the national legislation, starting from $1^{\text {st }}$ January 2020, the maximum annual exposure must not exceed 20 $\mu \mathrm{g} / \mathrm{m}^{3}$, and this value is represented as a constant in Figure 2. As expected, values inside the living room (average of $19.32 \mu \mathrm{g} / \mathrm{m}^{3}$ ) are lower compared to those from the balcony (average of $37 \mu \mathrm{g} / \mathrm{m}^{3}$ ). Nevertheless, it is worth mentioning that although the sampling from living room took place in a space separated from the outdoor atmosphere by two rounds of tilted windows, the maximum value recorded for this type of particle matters was $22 \mu \mathrm{g} / \mathrm{m}^{3}$ and the minimum was not far behind. Furthermore, all values inside the balcony, thus separated only by one tilted window from the outside atmosphere, exceeded the annual maximum limit of $20 \mu \mathrm{g} / \mathrm{m}^{3}$. The highest value, of $54 \mu \mathrm{g} / \mathrm{m}^{3}$, represents almost three time the admissible value and the average for the balcony almost double. It must be mentioned that the weather was also monitored and no major differences were recorded. For the February-March 2020, the temperature varied between 5 and $20{ }^{\circ} \mathrm{C}$, very few and brief showers, and the relative humidity varied between 45 and $81 \%$.

For the same period, the reports for Galati city issued by the national agency presents a good air quality, using the beforementioned coding system. This coding system present 6 levels, based on each measured pollutant concentrations. If any of the five pollutants $\left(\mathrm{SO}_{2}, \mathrm{NO}_{2}, \mathrm{O}_{3}, \mathrm{CO}\right.$ and $\left.\mathrm{PM}_{10}\right)$ measured by the monitoring station reaches a high level, the overall air quality is considered to be of that level. For the considered period, the air quality level varied between 1 and 3 for all four monitoring stations in February [19] and between 1 and 4 for all four monitoring stations in March [20], meaning that no exceeding of maximum values for $\mathrm{PM}_{10}$ was recorded. Although the monitoring stations measure $\mathrm{PM}_{10}$ and the present study presents values for $\mathrm{PM}_{2.5}$, 
the overall quality of air samples might be compared since the $\mathrm{PM}_{10}$ fraction also incorporate fine particulate matters. However, as presented in [21], various methods or instrumentation used for measurements and different people or places involved, represent a big factor that might influence the outcome, especially regarding the fine fraction of the particulate matters. Also, in [22] data from a monitoring station in Galati city was used to demonstrate the dependence of particulate matter concentration from air on wind speed. All of these being considered, it can be stated that the air quality monitoring should continue in agglomerated cities and the national monitoring system could reevaluate the positioning of some monitoring stations or their supplementation, so that relevant data to create the premises for future actions in pollution mitigation. The city considered in this study is an industrial one, a steel company and a naval yard flanking it from west and east respectively. Also, a large number of vehicles (approx. 216,000, of all types [23]) ads as the major source of $\mathrm{PM}_{2.5}$ pollution especially inside the city and mostly for locations near roads with high traffic, like the one selected for this study. More detailed and relevant information regarding the air pollution could in the end be the starting point for measures needed to obtain a less polluted air and consequently less pollution related diseases.

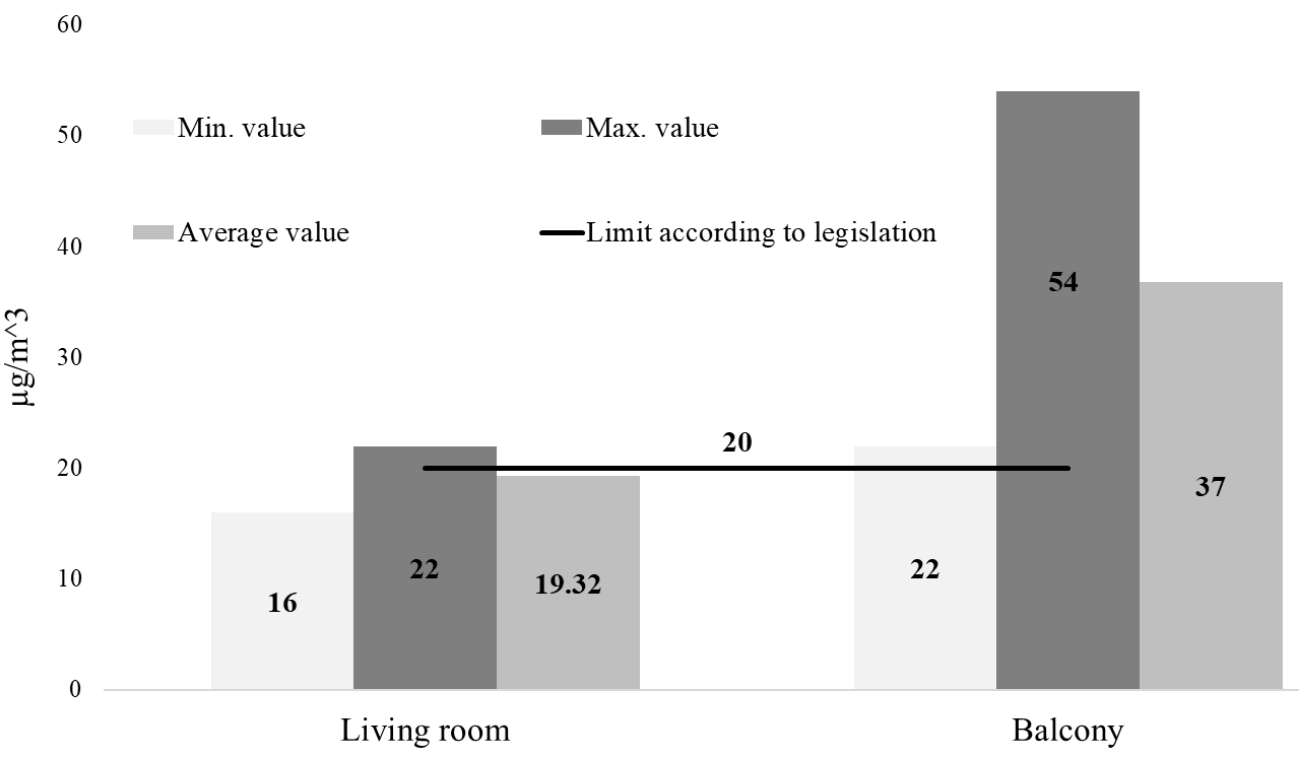

Fig. 2. Results of $P M_{2.5}$ concentration in air: minimum, maximum and average for Living room and Balcony measurements, compared with the limit according to Romanian legislation

\subsection{Heavy metal concentration in collected $P M_{2.5}$}

Particulate matters collected from the air samples contain different organic compounds or heavy metals that might negatively impact health population. Different studies around the world were focused on quantifying some of the possible heavy metals present in $\mathrm{PM}_{2.5}$. Some results are offered in Table 1, and the majority of studies present results from indoor measurements. Also, Table 1 contains results from the present study for the living-room and for the balcony measurements. As expected, values of all elements considered were higher for balcony samples, except for Cr. One of the many possible explanations, for this unexpected result, might be the intermittence of sampling, the Automated Aerosol Sampling Device being moved from one measurement space to the other in different days. To overcome this drawback, a second device, running in tandem, could be used in future measurement campaigns. Nevertheless, compared to the former study conducted in Galati, in a different outdoor site [15], the values for $\mathrm{Cr}, \mathrm{Mn}, \mathrm{Zn}, \mathrm{Fe}$ are comparable, lower for the present study, as expected, instead high values for $\mathrm{Fe}$ and $\mathrm{Zn}$ are again registered.

High values for $\mathrm{Zn}$ and $\mathrm{Fe}$ are also present in other studies conducted in cities with heavy industry, the highest value for $\mathrm{Fe}\left(1767,9 \mathrm{ng} / \mathrm{m}^{3}\right)$ being reported in Rooty Hill in Australia, and the highest value for $\mathrm{Zn}\left(950 \mathrm{ng} / \mathrm{m}^{3}\right)$ being reported in Beijing in China, while the lowest value for $\mathrm{Fe}\left(84.06 \mathrm{ng} / \mathrm{m}^{3}\right)$ was registered in the present study for living room measurements and the lowest value for $\mathrm{Zn}\left(34 \mathrm{ng} / \mathrm{m}^{3}\right)$ was registered in Córdoba, Argentina. High numbers were also registered for $\mathrm{Ba}$, although fewer studies measured this type of heavy element. Again, for $\mathrm{Ba}$, Beijing (China) registered the highest value $(523,65$ 
$\left.\mathrm{ng} / \mathrm{m}^{3}\right)$, this city also presenting highest values, from all compared studies, for $\mathrm{Mn}\left(85 \mathrm{ng} / \mathrm{m}^{3}\right)$ and $\mathrm{Sr}(60$ $\left.\mathrm{ng} / \mathrm{m}^{3}\right)$, while for $\mathrm{Ti}\left(167.5 \mathrm{ng} / \mathrm{m}^{3}\right)$ and $\mathrm{Cr}(121.7$ $\mathrm{ng} / \mathrm{m}^{3}$ ) the highest values were registered in Istanbul in Turkey and for $\mathrm{Rb}\left(3 \mathrm{ng} / \mathrm{m}^{3}\right)$ in Cairo, Egypt. It is expected that high concentrations of heavy metals to be present in populous cities and even higher in industrialized ones, this is why this type of agglomerations should be better monitored from the air pollution point of view. From data presented in this paper it can be observed, when compared with the air quality national monitoring system, that big differences might occur between different areas of the same city, this is why a greater involvement in this respect and the subsequent measures should be applied in the near future.

Table 2. Mean concentration of heavy elements in PM 2.5 from this study, compared to other studies $\left(\mathrm{ng} / \mathrm{m}^{3}\right)$

\begin{tabular}{ccccccccc}
\hline City (Country) & $\mathbf{T i}$ & $\mathbf{B a}$ & $\mathbf{C r}$ & $\mathbf{M n}$ & $\mathbf{F e}$ & $\mathbf{Z n}$ & $\mathbf{R b}$ & $\mathbf{S r}$ \\
\hline This study (balcony), Galați & 22.12 & 157.88 & 4.80 & 71.16 & 415.25 & 574.27 & 1.64 & 17.69 \\
(Romania) & & & & & & & & \\
This study (living room), Galați & 22.62 & 106.18 & 29.83 & 12.64 & 84.06 & 437.75 & 1.39 & 16.81 \\
(Romania) & & & & & & & & \\
Cairo (Egypt) [24] & 48 & NA & NA & 12 & 594 & 112 & $\mathbf{3}$ & 13 \\
Beijing (China) [14] & NA & $\mathbf{5 2 3 . 6 5}$ & 34.33 & $\mathbf{8 5}$ & NA & $\mathbf{9 5 0}$ & NA & $\mathbf{6 0}$ \\
Xian (China) [25] & 49 & NA & 5 & 50 & 806 & 587 & NA & 7 \\
Chongqing (China) [25] & 34 & NA & 4 & 41 & 408 & 152 & NA & 1 \\
Córdoba, (Argentina) [26] & 12 & ND & 4 & 14 & 325 & 34 & NA & NA \\
Thessaloniki (Greece) [27] & 45 & 125 & 23 & 35 & 426 & 110 & NA & 17 \\
Oporto (Portugal) [28] & NA & 2.65 & 4.01 & 3.54 & NA & 48.1 & 0.702 & 1.21 \\
Shiprock, NM (USA) [29] & 3.44 & 1.61 & NA & 0.93 & 44.7 & 1.22 & 0.1 & 0.37 \\
Istanbul (Turkey) [30] & $\mathbf{1 6 7 . 5}$ & 241.9 & $\mathbf{1 2 1 . 7}$ & 42.1 & 117.3 & 384.7 & 1.05 & 10 \\
Jeddah (Saudi Arabia) [31] & 55 & 34 & 2.1 & 19 & 590 & 41 & 1.2 & 4 \\
Monterrey (Mexico) [32] & NA & NA & 3.8 & 29.78 & 1026.18 & 39.19 & NA & NA \\
Rooty Hill (Australia) [33] & 8.9 & NA & 5.5 & 47.2 & $\mathbf{1 7 6 7 . 9}$ & 284.4 & NA & NA \\
\hline
\end{tabular}

\section{Conclusions}

As demonstrated by a large number of researches, the fine particulate matter in the breathable air is a major concern on public health. This is why the first obvious step is quantifying the extent of pollution with this type of pollutant. Numerous independent parties (e.g.: [34]) already started the monitoring of air in some big cities around the world and some surprising data already occurred, revealing that sometimes, the existing national monitoring system is unable to present the real extent of air pollution. Complementary to those situations, the present study demonstrates again this possibility, by comparing data regarding fine particulate matter concentration from an indoor site with data regarding the air quality from four monitoring stations of the national system during the same period (FebruaryMarch 2020). While in the present study the legislative limit was exceeded by the measurements inside a balcony (a mean value of almost two times being registered), and the measurements inside a living-room almost reached the maximum admissible value, the four existing monitoring stations in the same city presented a maximum level of 4 out of 6 for the air quality. Although different types of measurement techniques and other influencing factors could be a reason for these differences, it is clear that reevaluation of monitoring sites positioning or supplementation could be a possibility worth considering. Meanwhile, independent measurements will continue, and the present study will be followed by others, monitoring particulate matters at the same time in different sites being one of the goals. Also, measuring this type of pollutant at the same time in the same site and at different heights might shed some light regarding the dispersion of particulate matters inside artificial canyons formed by roads flanked by high buildings.

Measurements of $\mathrm{PM}_{2.5}$ concentration were completed by heavy metal concentration analyses. Data obtained this way were compared with results of other studies worldwide, most of them dealing with indoor $\mathrm{PM}_{2.5}$ measurements. Of all heavy metals considered, highest values were registered for $\mathrm{Fe}$ and $\mathrm{Zn}$ in this study, compared with a former study conducted in an outdoor site from Galati city. Similar situations were also registered for all the other studies, higher values, as expected, being recorded in agglomerated and industrialized cities, the study conducted in Beijing being the one presenting the highest values for 4 out of 8 heavy metals considered (Ti, Ba, Cr, Mn, Fe, Zn, Rb and Sr). Results from the present study could be further supplemented in the 
future with data from other type of analysis methodologies, such as X-ray diffraction, for $\mathrm{PM}_{2.5}$ mineralogical composition and scanning electron microscopy, for morphologic analysis purposes.

\section{References}

[1]. ***, Directiva 2008/50/CE a Parlamentului European si a Consiliului din 21 mai 2008 privind calitatea aerului înconjurător si un aer mai curat pentru Europa, Parlamentul European si Consiliul, Jurnalul Oficial al Uniunii Europene, 2008.

[2]. ***, Normativ din 2 iulie 2007 privind stabilirea indicilor de calitate a aerului in vederea facilitarii informarii publicului, Monitorul Oficial al Romaniei, 2007.

[3]. ***, Legea nr. 104/2011 privind calitatea aerului inconjurator, Monitorul Oficial al Romaniei, 2011.

[4]. ***, Measurement of $P M_{2.5}$ and $P M_{10}$ in outdoor air with the Harvard impactor, European Study of Cohorts for Air Pollution Effects, p. 1-13, 2008.

[5]. Oroian I., Laura Paulette C., Iederan P., Burduhos I., Brașovean C. B., Modalităţi de cuantificare a $P M_{10}$ şi $P M_{2,5}$ din aerul ambiental utilizând metoda standardizată, Pro Environment, vol. 2, p. 68-72, 2009.

[6]. ***, Particulate pollution - $P M_{10}$ and $P M_{2.5}$, News and views from Diamond Environmental Ltd., p. 1-5, 2016.

[7]. Martins N. R., Carrilho da Graça G., Impact of $P_{2.5}$ in indoor urban environments: A review, Sustainable Cities and Society, vol. 42, no. May, p. 259-275, 2018.

[8]. Tsoli S., Ploubidis G. B., Kalantzi O. I., Particulate air pollution and birth weight: A systematic literature review, Atmospheric Pollution Research, vol. 10, no. 4, p. 1084-1122, 2019.

[9]. Roumié M., The collaborative IAEA TC project on the investigation of fine and coarse atmospheric particulate matter in Arasia region, AccApp 2017: The Expanding Universe of Accelerator Applications, vol. 5, p. 147-154, 2018.

[10]. Yorifuji T., Kashima S., Doi H., Acute exposure to fine and coarse particulate matter and infant mortality in Tokyo, Japan (2002-2013), Sc. of the Total Env., vol. 551-552, p. 66-72, 2016.

[11]. Pallavi P., Sarath K. G., Richard E. P., Exposure to particulate matter in India: A synthesis of findings and future directions, Environmental Research, vol. 147, p. 480-496, 2016.

[12]. Yan Wang M. T., PM ${ }_{2.5}$ induces autophagy and apoptosis through endoplasmic reticulum stress in human endothelial cells, Science of the Total Environment, vol. 710, p. 1-13, 2020.

[13]. Pan S., Du S., Wang X., Zhang X., Xia L., Liu J., Pei F., Wei Y., Analysis and interpretation of the particulate matter $\left(P M_{10}\right.$ and $P M_{2.5}$ ) concentrations at the subway stations in Beijing, China, Sust. Cities and Society, vol. 45, p. 366-377, 2019.

[14]. Yang Gao H. J., Microscopic morphology and seasonal variation of health effect arising from heavy metals in $P M_{2.5}$ and $P M_{10}$ : One-year measurement in a densely populated area of urban Beijing, Atmospheric Research, vol. 212, no. 30, p. 213-226, 2018. [15]. Bodor M., Baltă Ștefan, Pintilie C., Lazăr L., Buruiană D., Studies regarding the distribution and composition of particulate matters in the air of an industrialized city, International Multidisciplinary Scientific GeoConference: SGEM: Surveying Geology \& mining Ecology Management, vol. 2, p. 587-591, 2016. [16]. Eeftens M., Tsai M. Y., et al., Spatial variation of $P M_{2.5}$, $P M_{10}, P M_{2.5}$ absorbance and PMcoarse concentrations between and within 20 European study areas and the relationship with $\mathrm{NO}_{2}$ - Results of the ESCAPE project, Atmospheric Environment, vol. 62 , p. 303-317, 2012.
[17]. ***, National Air Quality Monitoring Network, http://www.calitateaer.ro/public/home-page/?_locale=en, 2020. [18]. ***, www.anpm.ro, 2020.

[19]. ***, Evolutia calitatii aerului in luna februarie 2020 in judetul Galati, Agentia pentru Protectia Mediului Galati, http://www.anpm.ro/documents/19877/47762207/BI februarie+20 20.pdf/02ff1a65-02b3-4974-92a8-f45088c2107b, 2020.

[20]. ***, Evolutia calitatii aerului in luna martie 2020 in judetul Galati, Agentia pentru Protectia Mediului Galati, http://www.anpm.ro/documents/19877/48498296/Buletin+martie_2 020.pdf/9f146827-4bca-4942-a258-3cff5f645f40, 2020.

[21]. ***, Fine Particulate Matter $\left(P M_{2.5}\right)$ in the United Kingdom, Air Quality Expert Group, 2012.

[22]. Paraschiv S., Paraschiv L. S., Effects of wind speed, relative humidity, temperature and air pressure on $P M_{10}$ concentration for an urban background area, IOP Conference Series: Materials Science and Engineering, vol. 595, no. 1, 2019.

[23]. ***, Vehicule rutiere inmatriculate in circulatie la sfarsitul anului, pe categorii de vehicule, tipuri de proprietate, macroregiuni, regiuni de dezvoltare si judete, Institutul National de Statistica, http://statistici.insse.ro:8077/tempoonline/\#/pages/tables/insse-table, 2020.

[24]. Shaltout A. A., Hassan S. K., et al., Comparative elemental analysis of fine particulate matter $\left(P M_{2.5}\right)$ from industrial and residential areas in Greater Cairo-Egypt by means of a multisecondary target energy dispersive $X$-ray fluorescence spectrometer, Spectrochimica Acta - Part B Atomic Spectroscopy, vol. 145, p. 29-35, 2018.

[25]. Wang Z., Liu J., Springtime PM ${ }_{2.5}$ elemental analysis and polycyclic aromatic hydrocarbons measurement in High-rise residential buildings in Chongqing and Xian, China, Energy and Buildings, vol. 173, p. 623-633, 2018.

[26]. López M. L., et al., Elemental concentration and source identification of $P M_{10}$ and $P M_{2.5}$ by $S R-X R F$ in Córdoba City, Argentina, Atmospheric Environment, vol. 45, no. 31, p. 54505457, 2011.

[27]. Gemenetzis P., Moussas P., Arditsoglou A., Samara C., Mass concentration and elemental composition of indoor $\mathrm{PM}_{2.5}$ and $P M_{10}$ in University rooms in Thessaloniki, northern Greece, Atmospheric Environment, vol. 40, no. 17, p. 3195-3206, 2006.

[28]. Oliveira M., et al., Assessment of air quality in preschool environments (3-5 years old children) with emphasis on elemental composition of $P M_{10}$ and $P M_{2.5}$, Environmental Pollution, vol. 214, p. 430-439, 2016

[29]. Gonzalez-Maddux C., et al., Elemental composition of $P M_{2.5}$ in Shiprock, New Mexico, a rural community located near coalburning power plants and abandoned uranium mine tailings sites, Atmospheric Pollution Research, vol. 5, no. 3, p. 511-519, 2014.

[30]. Onat B., Sahin U. A., Akyuz T., Elemental characterization of $P M_{2.5}$ and $P M_{1}$ in dense traffic area in Istanbul, Turkey, Atmospheric Pollution Research, vol. 4, no. 1, p. 101-105, 2013.

[31]. Khodeir M., et al., Source apportionment and elemental composition of $\mathrm{PM}_{2.5}$ and $P M_{10}$ in Jeddah City, Saudi Arabia, Atmospheric Pollution Research, vol. 3, no. 3, p. 331-340, 2012.

[32]. González L. T., et al., Determination of trace metals in TSP and $P_{2.5}$ materials collected in the Metropolitan Area of Monterrey, Mexico: A characterization study by XPS, ICP-AES and SEM-EDS, Atmospheric Research, vol. 196, no. April, p. 8-22, 2017.

[33]. Mohiuddin K., Strezov V., Nelson P. F., Stelcer E., Characterisation of trace metals in atmospheric particles in the vicinity of iron and steelmaking industries in Australia, Atmospheric Environment, vol. 83, p. 72-79, 2017.

[34]. ***, https://www.uradmonitor.com/, 2020. 